\title{
Systematic review of the occurrence of infantile colic in the community
}

\author{
P L B J Lucassen, W J J Assendelft, J Th M van Eijk, J W Gubbels, A C Douwes, \\ W J van Geldrop
}

Institute for Research in Extramural Medicine, Vrije Universiteit, Amsterdam, Netherlands P L B J Lucassen $\mathrm{J}$ Th $M$ van Eijk

Department of General Practice, University of Amsterdam, Netherlands W J J Assendelft

Organisation for Research and Policy Advice, Grave, Netherlands J W Gubbels

Department of Pediatrics, University Hospital VU, Amsterdam, Netherlands A C Douwes

Scientific Committee of the Dutch College of General Practitioners, Utrecht, Netherlands W J van Geldrop

Correspondence to: Dr P L B J Lucassen, Akkerroosstraat $18,5761 \mathrm{EX}$ Bakel, Netherlands p.lucassen1@chello.nl

Accepted 15 November 2000

\begin{abstract}
Aims-To assess the occurrence of infantile colic in the community and the need for professional help; and to study the influences of potential determinants of infantile colic.

Methods-Surveys were identified by a systematic search in Medline (1966-98) and Embase (1988-98). Retrieved publications were checked for references. Studies selected were community based, prospective, and retrospective surveys on the occurrence of infantile colic published in English, German, French, or Dutch. Occurrence rates were calculated as percentages. Methodological quality of the surveys was assessed by two assessors independently with a standardised criteria list containing items on method of data gathering, definition of colic, and drop out rate.

Results-Fifteen community based surveys were identified. The methodological quality varied considerably and was generally low. Even the two most methodologically sound prospective studies yielded widely varying cumulative incidence rates of $5-19 \%$. Referral rates or the need to seek help because of crying were consistently lower than occurrence rates for prolonged crying as such. Gender, socioeconomic class, type of feeding, family history of atopy, and parental smoking were not shown to be associated with colic. Conclusion-Occurrence rates of infantile colic vary greatly according to methodological quality. A considerable number of parents reporting prolonged crying do not seek or need professional help. (Arch Dis Child 2001;84:398-403)
\end{abstract}

Keywords: infantile colic; community; incidence

The reported occurrence rates of infantile colic vary from $10 \%$ to $40 \% .^{1-4}$ Many reviews only use data from selected populations. ${ }^{3-8}$ Differences may reflect differences in definitions, methods of data gathering, and study design.

In epidemiological and more clinically oriented studies, infantile colic has been defined in different ways but prolonged crying is an almost constant feature. However, studies define normal and prolonged crying differently. The most commonly accepted is the "rule of 3": crying during at least three hours per day on at least three days of at least three weeks. The first two features originated from a description by Wessel and colleagues. ${ }^{9}$ The third is often not established because of problems in documenting the condition. Other time criteria that have been used are: severe crying for several hours per day, ${ }^{10}$ crying for more than two hours per day, ${ }^{11}$ and overall duration of more than three hours per day. ${ }^{12}$ Studies not using an indication of crying time define infantile colic as unexplained crying, ${ }^{13}$ crying seen as a problem, ${ }^{14}$ or crying with which parents felt they could no longer cope and for which they sought help. ${ }^{15}$ Other sources of variability are the presence of symptoms possibly of gastrointestinal origin (a high pitched pain cry, ${ }^{1}$ flatulence, and difficulties with the passage of stools ${ }^{16}$ ) and the emphasis on consolability. ${ }^{1}$ Apart from these differences, studies generally agree that infants with colic are healthy, thriving, and below 6 months of age. The foregoing could be congruent with two underlying concepts. Firstly, infantile colic is conceived as one distinct entity with prolonged crying as the main symptom and several optional additional features. Secondly, infantile colic is conceived as a collection of different entities, each defined separately.

Different methods have been used to establish the diagnosis, including audiotape recordings, ${ }^{17}$ parental diaries, ${ }^{18}$ the Crying Patterns Questionnaire (CPQ), ${ }^{19}$ non-specified questionnaires, and interviews, personal or by telephone. Crying has been classified in various ways, such as amount of crying in hours per day or answers to a broad question on whether the baby cried a lot. Moreover, some studies assessed crying prospectively with an inception early in life, whereas others used a retrospective data gathering method, sometimes up to $14-28$ months. ${ }^{20}$

To evaluate the impact of infantile colic on health care and to plan research on infantile colic, exact data on its occurrence are needed. We aimed to perform a systematic review of community based surveys to assess the occurrence of infantile colic and to assess the need for professional help related to study quality (method of data gathering, definition of infantile colic, and drop out rate). We also aimed to assess occurrence rates according to source of recruitment. Finally, we planned to assess the influence of prognostic factors such as gender and socioeconomic class, and aetiologic factors such as type of feeding, parental smoking, and family history of atopy on estimates of occurrence of infantile colic.

\section{Methods}

SELECTION OF STUDIES

In March 1998 we performed a Medline (1966-98) and an Embase (1988-98) search with the following search strategy: "colic" and 
Table 1 Community based prospective studies with occurrence rates for infantile colic, ranked according to methodological quality

\begin{tabular}{|c|c|c|c|c|c|c|c|}
\hline $\begin{array}{l}\text { First author } \\
\text { Country } \\
Q S^{\star}\end{array}$ & $\begin{array}{l}\text { Source of study population } \\
\text { Infant's age at assessment } \\
\text { Methods of data collection }\end{array}$ & $\begin{array}{l}\text { Definition of infantile colic as used for } \\
\text { occurrence estimate }\end{array}$ & $\begin{array}{l}\text { Period of } \\
\text { data } \\
\text { reporting on } \\
\text { occurrence }\end{array}$ & $\begin{array}{l}\text { Eligible } \\
(n)\end{array}$ & $\begin{array}{l}\text { Recruited } \\
\text { (n) }\end{array}$ & $\begin{array}{l}\text { Completed } \\
\text { study }(n)\end{array}$ & $\begin{array}{l}\text { Occurrence of } \\
\text { infantile colic } \\
(\%)\end{array}$ \\
\hline Canivet $^{29} \ddagger$ & Newborns from hospital & $\begin{array}{l}1 \text { Wessel's criteria\# or medication } \\
\text { prescribed }\end{array}$ & $\begin{array}{l}0-3 \\
\text { months }\end{array}$ & 409 & 209 & 152 & $5 \%$ \\
\hline Sweden & $\begin{array}{l}\text { Infants followed from birth to } 12 \\
\text { weeks }\end{array}$ & $\begin{array}{l}2 \text { Wessel's criteria without the } 3 \text { weeks } \\
\text { criterion }\end{array}$ & & & & & $11 \%$ \\
\hline \multirow[t]{2}{*}{$\mathrm{QS}=4$} & $\begin{array}{l}\text { Weekly diary for } 1 \text { day, questionnaire } \\
\text { (crying a problem?) }\end{array}$ & $\begin{array}{l}3 \text { Crying/screaming }>1 \text { hour/day during } 4 \\
\text { days/week in one week }\end{array}$ & & & & & $17 \%$ \\
\hline & & 4 Crying is a problem for the mother & & & & & $3 \%$ \\
\hline Høgdal $^{32}$ & Newborns from hospital & Unexplained paroxysms of crying or fussing & $0-6$ & 435 & 365 & 360 & $19 \%$ \\
\hline Denmark & $\begin{array}{l}\text { Infants followed from birth to } 6 \\
\text { months }\end{array}$ & $\begin{array}{l}\text { for at least } 90 \text { minutes each day for a } \\
\text { minimum of } 6 \text { of the preceding } 7 \text { days or }\end{array}$ & months & & & & \\
\hline $\mathrm{QS}=4$ & $\begin{array}{l}\text { Structured telephone interviews at age } \\
1-2-6 \text { months }\end{array}$ & $\begin{array}{l}\text { periods lasting at least } 3 \text { hours a day in } 3 \text { of } \\
\text { the preceding } 7 \text { days }\end{array}$ & & & & & \\
\hline Rubin $^{35}$ & Newborns from hospital & Unexplained prolonged crying & $0-3$ & 1269 & 1146 & 1019 & $26 \%$ \\
\hline & Infants followed from birth to 1 year & & months & & & & \\
\hline $\mathrm{QS}=3$ & $\begin{array}{l}\text { Mothers kept record of any problem } \\
\text { on feeding/crying }\end{array}$ & & & & & & \\
\hline Michelsson $^{28}$ & Well baby clinics & $\begin{array}{l}\text { Crying with which mothers felt the need to } \\
\text { seek help }\end{array}$ & $\begin{array}{l}0-3 \\
\text { months }\end{array}$ & $\mathrm{nr}$ & $\mathrm{nr}$ & 78 & $5 \%$ \\
\hline Finland & Infants under age 1 year & or & & & & & \\
\hline $\mathrm{QS}=2$ & $\begin{array}{l}\text { Questionnaire and 24-hour diary at } \\
\text { arbitrary visit } \dagger\end{array}$ & Crying for more than 3 hours per day & & & & & $14 \%$ \\
\hline Rautava $^{37}$ & Birth register & 5 item scale, ranging from no colic to a lot & $0-3$ & 1582 & 1443 & 1204 & $28 \%$ \\
\hline Finland & Infants at age 3 months & of colic; colic defined as "a lot of colic" and & months & & & & \\
\hline $\mathrm{QS}=2$ & Questionnaire given at scheduled visit & "quite a lot of colic" & & & & & \\
\hline Rinne $^{41} \mathrm{~S}$ & Well baby clinics & Question: how much does the baby cry? & $0-3$ & $\mathrm{nr}$ & $\mathrm{nr}$ & 113 & $12 \%$ \\
\hline Finland & Infants under age 1 year & Data on infants under 3 months crying & months & & & & \\
\hline $\mathrm{QS}=2$ & Questionnaire $\ddagger$ & more than 3 hours/day are given & & & & & \\
\hline Lehtonen $^{33}$ & Newborns from hospital & Paroxysms of crying for 3 or more hours & $0-3$ & $\mathrm{nr}$ & 1221 & 959 & $13 \%$ \\
\hline Finland & $\begin{array}{l}\text { Infants followed from birth to } 3 \\
\text { months }\end{array}$ & $\begin{array}{l}\text { per day, } 3 \text { days or more per week during at } \\
\text { least } 3 \text { weeks }\end{array}$ & months & & & & \\
\hline $\mathrm{QS}=1$ & $\begin{array}{l}\text { Questionnaire given at birth to be } \\
\text { returned at } 3 \text { months }\end{array}$ & & & & & & \\
\hline Hide $^{34}$ & Birth register & Mother's interpretation of the infant's cry & $0-3$ & $\mathrm{nr}$ & $\mathrm{nr}$ & 843 & $16 \%$ \\
\hline UK & Infants followed from birth to 1 year & as colic & months & & & & \\
\hline $\mathrm{QS}=1$ & $\begin{array}{l}\text { Health visitors recorded data at } \\
6-12-26-52 \text { weeks }\end{array}$ & & & & & & \\
\hline
\end{tabular}

${ }^{\star} \mathrm{QS}=$ quality score: range $0-6$ (for details see table 3 ).

†Data on infants younger than 3 months.

¥Study with prospective and retrospective part; only prospective data in table.

$\lceil\mathrm{nr}=$ not reported.

\Study on Finnish and Colombian infants; only data on Finnish infants in table.

\#Wessel's criteria: crying for 3 hours or more on at least 3 days in at least 3 weeks.

"crying" as keywords, and "colic", "cry", and "fuss" as free text words were combined with "epidemiology" (explode) as key word and "incidence", "prevalence", and "morbidity" as free text words. To contain sensitivity of the search, we did not search with the "restrict to focus" option. ${ }^{21}$ The searches were limited to infants younger than 1 year and restricted to English, German, French, and Dutch languages. We checked the references of retrieved publications for missing studies. The first author screened all citations in articles about incidence or prevalence of infantile colic in community based samples. Publications on consultation rates for crying and studies on non-white infants were excluded because our aim was to generate data on infants in Western societies.

We defined community based studies as those including infants recruited from well baby clinics or community populations. Studies recruiting infants born in hospital, but otherwise without problems, were also accepted as representative of the general population. We labelled a study prospective when data collection was performed during the crying period and retrospective when data were collected after resolution of the crying problem.

METHODOLOGICAL QUALITY

We evaluated methodological quality with a self developed scale, based on Laupacis and colleagues $^{22}$ and Fletcher and colleagues. ${ }^{23} \mathrm{We}$ used different versions for prospective and retrospective surveys. Each study was scored on the items "definition of infantile colic", "method of obtaining data on crying behaviour", and "drop out". The adequacy of each item could be scored "yes" or "no". Each item had a weight of 1 or 2 . In prospective studies the quality score ranged from 0 to 6 , with a low score indicating high susceptibility to bias. The score of retrospective studies had a range from 0 to 5 . Two of us (WJvG, PLBJL) scored all surveys independently. We were not blinded for information on authors and journal, because one of us was well acquainted with the material already. Disagreement was solved by consensus. The degree of agreement before the consensus meeting was expressed as a percentage agreement and as kappa. ${ }^{24} 25$

\section{OCCURRENCE RATES}

Occurrence rates of infantile colic in prospective studies are usually given as cumulative incidence rates and occurrence rates from retrospective studies as period prevalence rates. ${ }^{26}$ However, both rates are identical when studying an ailment that only occurs in the first four months of life. Whenever possible, we extracted data from the original publications to calculate occurrence rates over the period in which infantile colic usually presents - that is, the first three months of infancy. For all data, 
Table 2 Community based retrospective studies with occurrence rates for infantile colic, ranked according to methodological quality

\begin{tabular}{|c|c|c|c|c|c|c|c|}
\hline $\begin{array}{l}\text { First author } \\
\text { Country } \\
Q S^{\star}\end{array}$ & $\begin{array}{l}\text { Source of study population } \\
\text { Infant's age at assessment } \\
\text { Method of data collection }\end{array}$ & $\begin{array}{l}\text { Definition of infantile colic as used for occurrence } \\
\text { estimate }\end{array}$ & $\begin{array}{l}\text { Period of } \\
\text { data } \\
\text { reporting on } \\
\text { occurrence }\end{array}$ & $\begin{array}{l}\text { Invited } \\
(n)\end{array}$ & $\begin{array}{l}\text { Participated } \\
\text { (n) }\end{array}$ & \multicolumn{2}{|c|}{$\begin{array}{l}\text { Occurrence } \\
\text { of infantile } \\
\text { colic (\%) }\end{array}$} \\
\hline van der Wal ${ }^{43}$ & Well baby clinic & 1 Crying $>3$ hours/day & $0-3$ & \multirow[t]{3}{*}{2180} & \multirow[t]{3}{*}{1826} & 1 & $8 \%$ \\
\hline Netherlands & Infants at age $2-3$ months & 2 Crying a lot & \multirow[t]{2}{*}{ months } & & & 2 & $14 \%$ \\
\hline $\mathrm{QS}=5$ & $\begin{array}{l}\text { Questionnaires to be filled out by } \\
\text { nurse/physician at scheduled visit and } \\
\text { questionnaire at home }\end{array}$ & 3 Difficult to comfort & & & & 3 & $10 \%$ \\
\hline Canivet $^{29} \dagger$ & Newborns from hospital & 1 Wessel's\# criteria or needed medication & $0-3$ & \multirow[t]{3}{*}{254} & \multirow[t]{3}{*}{224} & 1 & $12 \%$ \\
\hline Sweden & $\begin{array}{l}\text { Infants from mothers who refused to } \\
\text { participate in prospective study }\end{array}$ & $\begin{array}{l}2 \text { Crying/screaming }>1 \text { hour per day during } 4 \\
\text { days/week, in one week }\end{array}$ & \multirow[t]{2}{*}{ months } & & & 2 & $15 \%$ \\
\hline $\mathrm{QS}=4$ & Telephone interview at age $5-7$ months & 3 Crying is a problem for the mother & & & & 3 & \multirow[t]{4}{*}{$12 \%$} \\
\hline Lothe $^{31}$ & Newborns from hospital & \multirow{3}{*}{$\begin{array}{l}\text { Intermittent unexplained excessive crying, } \\
\text { many times a day, at least } 4 \text { days a week, and } \\
\text { continuing for } 1 \text { week, at least } 3 \text { hours per day }\end{array}$} & \multirow{3}{*}{$\begin{array}{l}0-3 \\
\text { months }\end{array}$} & \multirow[t]{3}{*}{242} & \multirow{3}{*}{219} & \multirow[t]{3}{*}{$17 \%$} & \\
\hline Sweden & Infants followed from birth to 12 weeks & & & & & & \\
\hline $\mathrm{QS}=4$ & $\begin{array}{l}\text { 1. Questionnaire given at birth }(\mathrm{n}=78) \\
2 \text {. Telephone interview at } 3-4 \text { months } \\
(\mathrm{n}=141)\end{array}$ & & & & & & \\
\hline St James-Roberts ${ }^{19}$ & Birth register & Referral to professional for crying & $1-3$ & \multirow[t]{3}{*}{ nr\$ } & \multirow[t]{3}{*}{100} & \multirow{2}{*}{\multicolumn{2}{|c|}{$10 \%$}} \\
\hline UK & Infants under age 1 year & or & months & & & & \\
\hline $\mathrm{QS}=4$ & Mailed questionnaire $(\mathrm{CPQ}) \ddagger$ & Crying for more than 3 hours per day & & & & $29 \%$ & \\
\hline Alvarez $z^{30}$ & Birth register & Need of professional help & $0-3$ & \multirow[t]{3}{*}{174} & \multirow[t]{3}{*}{140} & \multirow{2}{*}{\multicolumn{2}{|c|}{$15 \%$}} \\
\hline Denmark & Infants under age 1 year & or & \multirow[t]{2}{*}{ months } & & & & \\
\hline $\mathrm{QS}=4$ & Mailed questionnaire (CPQ) & Crying for more than 3 hours per day & & & & \multicolumn{2}{|l|}{$21 \%$} \\
\hline Crowcroft $^{42}$ & Birth register & \multirow[t]{2}{*}{ Question: was your baby colicky? } & \multirow[t]{2}{*}{$0-1$ month } & \multirow[t]{2}{*}{72995} & \multirow[t]{2}{*}{67172} & \multirow[t]{2}{*}{$18 \%$} & \\
\hline $\begin{array}{l}\mathrm{UK} \\
\mathrm{QS}=3\end{array}$ & $\begin{array}{l}\text { Questionnaire administered by health } \\
\text { visitor at age } 1 \text { month }\end{array}$ & & & & & & \\
\hline Thomas ${ }^{36}$ & Source not reported & \multirow{3}{*}{$\begin{array}{l}\text { Recurrent episodes of unexplained crying and } \\
\text { irritability }>1 \text { week }\end{array}$} & \multirow{3}{*}{$\begin{array}{l}2-52 \\
\text { weeks }\end{array}$} & \multirow[t]{3}{*}{1022} & \multirow[t]{3}{*}{964} & \multirow{3}{*}{\multicolumn{2}{|c|}{$20 \%$}} \\
\hline USA & Infants 2 weeks to 12 months of age & & & & & & \\
\hline $\mathrm{QS}=2$ & Questionnaire personal or by telephone & & & & & & \\
\hline Ståhlberg $^{20}$ & Birth register & \multirow{2}{*}{$\begin{array}{l}\text { Gas problems or infantile colic leading to } \\
\text { unexplained periods of crying and restlessness }\end{array}$} & \multirow{2}{*}{$\begin{array}{l}\text { 'Early } \\
\text { infancy' }\end{array}$} & \multirow[t]{2}{*}{431} & 323 & $40 \%$ & \\
\hline $\begin{array}{l}\text { Finland } \\
\mathrm{QS}=0\end{array}$ & $\begin{array}{l}\text { Mailed questionnaire to each } 10^{\text {th }} \text { child } \\
\text { at age } 14-38 \text { months }\end{array}$ & & & & & & \\
\hline
\end{tabular}

${ }^{\star} \mathrm{QS}=$ quality score; range $0-5$ (for details see table 4 ).

†Study with prospective and retrospective part; only retrospective data in table.

‡CPQ: crying patterns questionnaire.

TThe definition including the 3 weeks criterion was considered unrealistic to search for retrospectively (see table 1).

Snr: not reported.

\#Wessel's criteria: crying for 3 hours or more on at least 3 days in at least 3 weeks.

$95 \%$ confidence intervals (CI) were calculated. ${ }^{27}$ Pooling of the data was a priori considered not suitable because of heterogeneity in design, method of obtaining data, and definition of infantile colic.

\section{Results}

The Medline search revealed 87 citations (33 on the subject of infantile colic); the Embase search yielded 52 citations ( 26 on the subject of infantile colic). Of these citations 16 were on the epidemiology of infantile colic/prolonged crying. ${ }^{19} 2028-41$ Moreover, we located one not yet included in Medline ${ }^{42}$ and one submitted study. ${ }^{43}$ Reference checking yielded no additional publications. One study was excluded because it was performed in non-white infants. ${ }^{39}$ We excluded two other studies: one which gave data on mothers seeking help from their general practitioner, ${ }^{38}$ and one which had been performed in infants referred to a private paediatric clinic. ${ }^{40}$ Therefore, we report on 15 studies, ${ }^{19} 20$ 28-37 41-43 13 of which were identified on Medline, ${ }^{19} 20$ 28-3742 and five on Embase 5. ${ }^{19}{ }^{29-31} 33$ Most surveys had been performed in Scandinavian countries ${ }^{20} 28-33374$ and the UK. ${ }^{19} 343542$ Seven studies had a prospective design, ${ }^{28} 32-353741$ seven a retrospective design, ${ }^{19} 203031364243$ and one study had a prospective and retrospective part. ${ }^{29}$ Tables 1 and 2 present a tabular summary of the surveys.

The quality score ranged from 1 to 4 for the prospective studies and from 0 to 5 for retrospective studies. Tables 3 and 4 give details of the quality assessment. There was good interrater agreement on the summary quality score of prospective studies (agreement
$89 \%, \kappa$ 0.78). Agreement was moderate for retrospective studies (agreement $77 \%$, $\kappa$ 0.53). ${ }^{24}$ For prospective studies interrater agreement (expressed as $\kappa$ ) for drop out rates was 0.75 , for adequacy of the diagnosis 0.33 , and for assessment of the outcome 0.90 . For retrospective studies these figures were 0.25 , 0.53 , and 0.58 respectively. Most disagreement was caused by differences in interpretation or unclear reporting in the article and could be resolved easily. We reached consensus in all cases.

Occurrence rates in prospective studies varied from $3 \%$ to $28 \%$ and in retrospective studies from $8 \%$ to $40 \%$ (tables 1 and 2); refusal state (percentage of invited/recruited persons not participating) varied from $6 \%$ to $49 \%$; and loss to follow up in prospective studies (percentage of recruited persons not completing the study) varied from $1 \%$ to $27 \%$. Five studies did not use a time criterion in defining colic. ${ }^{20}{ }^{34-37}$ Six studies assessed occurrence of colic by measuring mothers' subjective interpretation of their infants' crying as "prolonged" or "colicky", without using a time

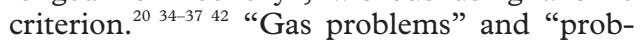
lems with comforting the infant" were each included once in the definition. ${ }^{20}{ }^{43}$ All except one survey (Canivet and colleagues, ${ }^{29}$ retrospective part), assessing infant crying behaviour and care seeking behaviour separately, found consistently lower occurrence rates for colic seen as a problem needing professional advice than for colic seen as prolonged crying for a certain period. ${ }^{19}{ }^{28-30}$

One of the two best prospective studies - the one using Wessel's "rule of 3 " stringently ${ }^{29}$ 
Table 3 Quality score of prospective studies, individual items and total score

\begin{tabular}{|c|c|c|c|c|c|c|c|c|}
\hline Item (weight)* & Canivet $^{29}$ & $H ø g d a l^{32}$ & Rubin ${ }^{35}$ & Michelsson ${ }^{28}$ & Rautava $^{37}$ & Rinne $^{41}$ & Lehtonen $^{33}$ & Hide $^{34}$ \\
\hline \multicolumn{9}{|l|}{ Drop out } \\
\hline Selection: $\%$ not included $<20 \%$ (1) & - & + & + & ? & + & ? & - & ? \\
\hline Follow up: loss to follow up $<20 \%$ (1) $\dagger$ & - & + & + & ? & + & + & - & ? \\
\hline Diagnosis-definition sufficient (1) & + & + & - & + & - & + & + & - \\
\hline \multicolumn{9}{|l|}{ Outcome (method) } \\
\hline Diary during at least 7 days (2) & + & - & - & - & - & - & - & - \\
\hline Diary less than 7 days (1) & - & - & - & + & - & - & - & - \\
\hline Other method $(0)$ & - & + & + & - & + & + & + & + \\
\hline \multicolumn{9}{|l|}{ Outcome (timing) } \\
\hline Multiple measurement periods (2) & + & + & + & - & - & - & - & + \\
\hline Single measurement period $(0)$ & - & - & - & + & + & + & + & - \\
\hline Total quality score $(0-6)$ & 4 & 4 & 3 & 2 & 2 & 2 & 1 & 0 \\
\hline
\end{tabular}

^Weight: score to compliance with item.

+ complied to item; - not complied to item; ? not stated.

†Loss to follow up includes non-participation and not completing the study after recruitment.

reported a relatively low incidence of infantile colic $(5 \%)$. The other high quality prospective study reported a much higher figure $(19 \%){ }^{32}$ None of the surveys separately reported the presence of gastrointestinal symptoms. Three surveys measured consolability. ${ }^{19} 3043$

Surveys recruiting cases from well baby clinics reported lower occurrence rates compared to recruitment from birth registers and hospitals. One survey did not state the source of recruitment. ${ }^{36}$

Eight studies reported on occurrence in boys and girls separately: seven found no difference in occurrence of colic, ${ }^{202-32} 3542$ and one reported a significantly higher proportion of boys crying more than three hours per day. ${ }^{43}$ Five studies reported on influence of socioeconomic class: three found no differences, ${ }^{20} 3537$ while two reported slightly higher rates in higher socioeconomic classes. ${ }^{34}$ Seven surveys compared breast fed and formula fed infants: four found no difference, ${ }^{29} 343637$ in two studies the occurrence rates among breast fed infants were slightly higher, ${ }^{35} 42$ and in one it was slightly lower. ${ }^{43}$ Only two studies reported separately on a positive family history of atopy: both found no association between the presence of a positive family history of atopy and the presence of infantile colic. ${ }^{20}{ }^{34}$ In two studies influence of parental smoking was detected. ${ }^{20} 29$

\section{Discussion}

Occurrence rates of infantile colic in community based samples vary greatly because of differences in study design, site of recruitment, definition, and method of data collection. The two best prospective studies yielded occurrence rates of $5 \%$ and $19 \%$ respectively. Our review stresses the importance of a uniform definition and good documentation methods.

Gender, socioeconomic status, type of feeding, parental smoking, and family history of atopy have not been consistently measured and in studies that presented data, no consistent influence on occurrence estimates were detected. For some surveys small study size with related low power, might have caused the inability to detect differences in subgroups.

We are interested to find that in a prospective study of 160 Korean infants ${ }^{39}$ (which we excluded) no case of infantile colic was found. This survey was adequate according to the quality criteria in this study as the researchers used a 24 hour diary and a definition of infantile colic that included a time criterion. Confirmation of this finding in other non-Western societies is needed as differences in diet or care taking activities may be responsible for differences in occurrence of infantile colic, possibly providing clues for prevention or treatment.

In our systematic review, we used an unvalidated quality assessment method. We were not aware of any existing methods for assessing quality of occurrence studies. Although the low agreement for some items may be a result of inadequate reporting in the original publication, inconsistencies in our method could also have played a role. Further development of quality assessment methods for occurrence studies is therefore needed.

The various surveys in the review actually assessed three different concepts of infantile colic: crying of a certain duration; crying as a problem for the mother; and crying leading to a need to seek professional help. Comparing the need for professional help with crying of certain duration (for example, more than three

Table 4 Quality score of retrospective studies, individual items, and total score

\begin{tabular}{|c|c|c|c|c|c|c|c|c|}
\hline Items $(\text { weight })^{*}$ & van der $\mathrm{Wal}^{43}$ & Canivet $^{29}$ & Lothe $e^{31}$ & St fames-Roberts ${ }^{19}$ & Alvare $^{30}$ & Crowcroft ${ }^{42}$ & Thomas ${ }^{36}$ & Ståhlberg ${ }^{20}$ \\
\hline Drop out - selection: $\%$ not included $<20 \%(1)$ & + & + & + & $?$ & - & + & + & - \\
\hline Diagnosis—definition sufficient (1) & + & + & + & + & + & - & - & - \\
\hline \multicolumn{9}{|l|}{ Outcome (method) } \\
\hline $\begin{array}{l}\text { Amount of crying in } \geqslant 3 \text { categories or } \\
\text { estimation of duration }(1)\end{array}$ & + & + & - & + & + & - & - & - \\
\hline $\begin{array}{l}\text { Yes/no answer to question whether child cries } \\
\text { much }(0)\end{array}$ & - & - & + & - & - & + & + & + \\
\hline Outcome (period of data collection) & & & & & & & & \\
\hline $0-4$ months of age $(2)$ & + & - & + & + & + & + & - & - \\
\hline $4-6$ months of age (1) & - & + & - & - & - & - & + & - \\
\hline After 6 months of age $(0)$ & - & - & - & - & - & - & - & + \\
\hline Total quality score $(0-5)$ & 5 & 4 & 4 & 4 & 4 & 3 & 2 & 0 \\
\hline
\end{tabular}

*Weight: score to compliance with item.

+ complied to item; - not complied to item; ? not stated. 
hours per day), in those studies which assessed both, ${ }^{12} 28$ most mothers seem to cope without professional help. It is not clear whether this discrepancy is caused by characteristics of the mother, characteristics of the infant (crying pattern and related features), or both. It is possible that consolability, the presence of gastrointestinal symptoms, and acoustic cry features (a more "painful" sound) are determinants of the decision to seek professional help. Moreover, distinguishing between crying of normal and excessive duration remains a problem. An older study had shown that healthy infants in Western societies cry for about 150 minutes per day at 2 weeks of age, for almost three hours per day (median) at 6 weeks and for about 60 minutes per day at 12 weeks. ${ }^{45}$ Recent research shows similar figures: St James Roberts and Hall ${ }^{19}$ measured a mean cry duration in normal infants aged 1-3 months of about two hours per day; and Lehtonen and Korvenranta $^{33}$ assessed maximum crying levels of about three hours per day in 4 week old healthy infants. So, although arbitrary, the three hour criterion seems to make sense as a distinction between normal and excessive.

In our opinion, surveys with a prospective design yield more reliable estimates of occurrence rates than retrospective studies, as the latter are prone to recall bias. The influence of this bias is greater in conditions measured subjectively, such as infantile colic. In spite of this, even the occurrence rates reported from prospective studies vary widely. Differences in methods of data collection may contribute to this. We assume the validated 24 hour diary ${ }^{46}$ to be the best diagnostic method in occurrence studies, but it seems impossible for parents to use this method daily for $12-16$ weeks. Therefore, as a compromise, Canivet et al used this method on one predetermined day each week. ${ }^{29}$ To further improve the diagnostic quality of estimating crying duration, this method could be supplied with the Crying Patterns Questionnaire, ${ }^{19}$ a validated ${ }^{47}$ retrospective method, which asks for an estimate of crying duration during the previous week.

As the studies in this review used a wide range of definitions and measurement methods, we can conclude little about infantile colic as a collection of different entities. ${ }^{20}{ }^{44}$ Future research should therefore aim to discern the importance of distinguishing the following entities: firstly, mothers complaining about their infants' crying, even though it is within normal limits; secondly, mothers complaining about an excessively crying infant who is consolable and has no additional gastrointestinal features; thirdly, mothers complaining about an infant with prolonged crying, who is unconsolable and has gastrointestinal features; and fourthly, mothers not complaining about, but reporting on request an infant who cries excessively. Important items to be assessed in a valid way are: the time spent crying, consolability, and gastrointestinal symptoms, including a high-pitched pain cry; and maternal characteristics, for example, general wellbeing and the presence of anxiety or depression. Data should preferably be gathered prospec- tively with diaries, combined with instruments aimed at measuring symptoms, such as the "Colic Symptom Checklist". ${ }^{19}$

We thank Anja van Guluck for her help in searching Medline/Embase and obtaining the articles, and Rosemarie Tomes for checking the English language.

1 Lehtonen LA, Rautava PT. Infantile colic: natural history and treatment. Curr Probl Pediatr 1996;26:79-85.

2 Thomas DB. Personal viewpoint. Of colic and rumbling in the guts. F Paediatr Child Health 1995;31:384-6.

3 Berkowitz CD. Management of the colicky infant. Compr Ther 1997;23:277-80.

4 Balon AJ. Management of infantile colic. Am Fam Physician 1997;55:235-44.

5 Hewson P, Oberklaid F, Menahem S. Infant colic, distress, and crying. Clin Pediatr 1987;26:69-76.

6 Leung AKC. Infantile colic. Am Fam Physician 1987;36: 153-6.

7 Keefe MR. Irritable infant syndrome: theoretical prespectives and practice implications. Adv Nurs Sci 1988;10:70-8. 8 Lester BM, Boukydis CFZ, Garcia-Coll CT, Hole WT. Colic for developmentalists. Infant Mental Health fournal 1990;11:321-33.

9 Wessel MA, Cobb JC, Jackson EB, et al. Paroxysmal fussing in infancy, sometimes called "colic". Pediatrics 1954;14: 421-34.

10 Lothe L, Lindberg T, Jakobsson I. Cow's milk formula as a cause of infantile colic: a double-blind study. Pediatrics 1982;70:7-10

11 Taubman B. Parental counseling compared with elimination of cow's milk or soy milk protein for the treatment of infant colic syndrome: a randomized trial. Pediatrics 1988;81:75661

12 Iacono G, Carroccio A, Montalto G, et al. Severe infantile colic and food intolerance: a long-term prospective study. $\mathcal{F}$ Pediatr Gastroenterol Nutr 1991;12:332-5.

13 Danielsson B, Hwang CP. Treatment of infantile colic with surface active substance (Simethicone). Acta Paediatr Scand 1985;74:446-50.

14 Barr RG, McMullan SJ, Spiess H, et al. Carrying as colic "therapy": a randomized controlled trial. Pediatrics 1991; 87:623-30.

15 McKenzie S. Troublesome crying in infants: effect of advice to reduce stimulation. Arch Dis Child 1991;66:1416-20.

16 St James-Roberts I. Persistent infant crying. Arch Dis Child 1991;66:653-5.

17 St James-Roberts I, Hurry J, Bowyer J. Objective confirmation of crying durations in infants referred for excessive
tion tion of crying durations in infants refe
crying. Arch Dis Child 1993;68:82-4.

18 Barr RG, Kramer MS, Boisjoly C, et al. Parental diary of infant cry and fuss behaviour. Arch Dis Child 1988;63:3807.

19 St James-Roberts I, Halil T. Infant crying patterns in the first year: normal community and clinical findings. $f$ Child Psychol Psychiatry 1991;32:951-68.

20 Ståhlberg M-R. Infantile colic: occurrence and risk factors. Eur F Pediatr 1984;143:108-11.

21 Greenhalgh T. How to read a paper. The Medline database. BMF 1997;315:180-3

22 Laupacis A, Wells G, Richardson WS, Tugwell P. User's guides to the medical literature V. How to use an article about prognosis. $\mathcal{F A M A} 1994 ; 272: 234-7$.

23 Fletcher RH, Fletcher SW, Wagner EH. Clinical epidemiolFletcher RH, Fletcher SW, Wagner EH. Clinical epidemi
ogy. The essentials. Baltimore: Williams \& Wilkins, 1988.

ogy. The essentials. Baltimore: Williams \& Wilkins, 1988.
Altman DG. Practical statistics for medical research. London: Chapman \& Hall, 1991:404-8.

25 Brennan P, Silman A. Statistical methods for assessing observer variability in clinical measures. BMF 1992;304: 1491-4.

26 Friedman GD. Primer of epidemiology. New York: McGrawHill, 1987:8-11

27 Gardner MJ, Altman DA. Calculating confidence intervals for proportions and their differences. In: Gardner MJ, Altman DG, eds. Statistics with confidence. London: BMJ Publications, 1989:28-34.

28 Michelsson K, Rinne A, Paajanen S. Crying, feeding and sleeping patterns in 1 to 12 month-old infants. Child Care Health Dev 1990;16:99-111.

29 Canivet C, Hagander B, Jakobsson I, Lanke J. Infantile colic-less than previously estimated? Acta Paediatr 1996; 85:454-8.

30 Alvarez M, St James-Roberts I. Infant fussing and crying patterns in the first year in an urban community in Denmark. Acta Paediatr 1996;85:463-6.

31 Lothe L, Ivarsson I-A, Ekman R, Lindberg T. Motilin and infantile colic. Acta Paediatr Scand 1990;79:410-16.

32 Høgdal CK, Vestermark V, Birch M, et al. The significance of pregnancy, delivery and postpartum factors for the development of infantile colic. $\mathcal{F}$ Perinat Med 1991;19: 251-7.

33 Lehtonen L, Korvenranta H. Infantile colic. Seasonal incidence and crying profiles. Arch Pediatr Adolesc Med 1995;149:533-6.

34 Hide DW, Guyer BM. Prevalence of infant colic. Arch Dis Child 1982;57:559-60.

35 Rubin SP, Prendergast M. Infantile colic: incidence and treatment in a Norfolk community. Child Care Health Dev 1984;10:219-26. 
36 Thomas DW, McGilligan K, Eisenberg LD, et al. Infantile colic and type of milk feeding. Am $\mathcal{F}$ Dis Child 1987;141: colic and

37 Rautava P, Helenius H, Lehtonen L. Psychosocial predisposing factors for infantile colic. BMf 1993;307:600-4.

38 Tasche MJA, Bruijnzeels MA, van der Poel BNM, et al. De veel huilende zuigeling: voorkomen en beleid in de huisartspraktijk. Ned Tijdschr Geneeskd 1993;137:1927-30.

39 Lee K. The crying pattern of Korean infants and related factors. Dev Med Child Neurol 1994;36:601-7.

40 Stagnara J, Blanc JP, Danjou G, et al. Éléments cliniques du diagnostic de coliques du nourrisson. Enquête chez 2773 nourrissons âgés de 15 à 119 jours. Arch Pediatr 1997;4:959-66.

41 Rinne A, Saenz AH, Michelsson K. Amount and perception of baby crying in Finland and Colombia. Early Child Der Care 1990;65:139-44.
42 Crowcroft NS, Strachan DP. The social origins of infantile colic: questionnaire study covering 76747 infants. BMF

43 Wal MF van der, Boom DC van den, Pauw-Plomp H, Jonge GA de. Mothers' reports of infant crying and soothing in the multi-cultural city of Amsterdam, the Netherlands. Submitted.

44 Barr RG, Rotman A, Yaremko J, et al. The crying of infants with colic: a controlled empirical description. Pediatrics 1992;90:14-21.

45 Brazelton TB. Crying in infancy. Pediatrics $1962 \cdot 29 \cdot 579-88$.

46 Barr RG, Kramer MS, Boisjoly C, et al. Parental diary of infant cry and fuss behavior. Arch Dis Child 1988;63:380-7.

47 Wolke D, Meyer R, Gray P. Validity of the crying pattern questionnaire in a sample of excessively crying babies. $f$ Reprod Infant Psychol 1994;12:105-14.

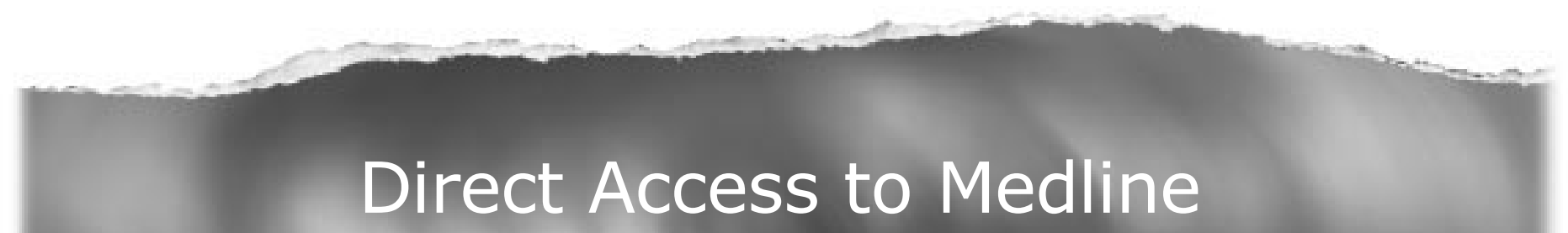

Medline

Link to Medline from the homepage and get straight into the National Library of Medicine's premier bibliographic database. Medline allows you to search across 9 million records of bibliographic citations and author abstracts from approximately 3,900 current biomedical journals.

www.archdischild.com 